\title{
Superficial, shallow and reactive
}

\author{
How a small state news media covers politics
}

\section{Jón Gunnar Ólafsson}

Faculty of Political Science, University of Iceland

\begin{abstract}
This article illustrates how the crisis of the news media is impacting political coverage in Iceland. Perceptions of routine political coverage in the Icelandic media have not been studied before, and this article fills this research gap and situates the Icelandic case within the wider news media crisis literature. My exploration is guided by two research questions. The first focuses on how journalists and politicians in Iceland perceive political coverage in the Icelandic media and how the coverage is seen to affect their working practices. The second question concerns how the public in Iceland perceives political news content. Findings show that, according to journalists and politicians, the mix of mainly commercial funding models and the smallness of the media market results in even more superficial and problematic coverage than in larger states. Survey answers illustrate that the public mostly agrees with interviewee perceptions concerning how the Icelandic media covers politics.
\end{abstract}

Keywords: political coverage, news media, Iceland, journalism, crisis

\section{Introduction}

In this article, I examine routine political news coverage in the Icelandic legacy media by analysing how Icelandic politicians, journalists, and the public perceive the coverage. The article fills a research gap, as perceptions of how the Icelandic media routinely covers politics have not been studied before. The article further shows how the Icelandic case can be situated within the wider literature on the crisis of the news media. The analysis is guided by two broad research questions: 1) How do journalists and politicians in Iceland perceive political coverage in the Icelandic legacy news media, and how is the coverage seen to affect their working practices? 2) How does the public in Iceland perceive the political coverage in comparison to journalists and politicians? I examine the answers to these questions in relation to the media's democratic roles of holding those in power to account, staging an open and public debate on important issues, and speaking for the people and representing their interests (Curran, 2002).

The article is in five main sections. The first section situates the Icelandic case within a wider context, and in the second section, I describe the methods and data collection. I then focus on how journalists and politicians perceive political coverage in the Icelandic

Ólafsson, J. G. (2021). Superficial, shallow and reactive: How a small state news media covers politics. Nordicom Review, 42(S2), 70-86. https://doi.org/10.2478/nor-2021-0018 
media in the third section, where the interview answers reveal striking similarities. Overall, journalists and politicians see political coverage as superficial, lacking in analysis and informed criticism. This was often compared to coverage in larger states, which was perceived as problematic as well, but also more diverse. The fourth section illustrates public perceptions, which echo those of politicians and journalists to a large degree. Political coverage is generally regarded by the public as superficial, lacking in critical questions and investigative work. In the fifth and final section, I discuss the perceived reasons behind the superficial coverage. Various points were raised by respondents, but by far the most dominant theme to emerge from the study focused on resource constraints and commercialisation, linked to Iceland's small media market.

\section{Journalism, politics, and a small media market in crisis}

Studies across North America, the UK, other parts of Europe, and the Nordic countries show how the news media operates in an increasingly challenging landscape (e.g., Currah, 2009; Davis, 2019; Ohlsson, 2015; Ohlsson \& Facht, 2017; McChesney \& Pickard, 2011; Siles \& Boczkowski, 2012). The traditional funding model of the commercial legacy news media has been breaking down, and there is now a crisis in the business model of news, with journalists finding it increasingly difficult to produce in-depth coverage based on original reporting (Phillips \& Witschge, 2012).

Before the more recent crisis debates, Blumler and Kavanagh (1999) argued that political journalism had been undermined by a strong market orientation, or an infotainment approach to politics. Subsequently, much of the research on the media-politics relationship has been placed under the mediatisation of politics umbrella. Put simply, this approach is based on the assumption that politics has become increasingly shaped by the media's own standards and what media considers newsworthy. With commercial funding models in crisis and less resources available than before, there is now less focus on policy discussions and more on horse-race coverage and click-friendly headlines that politicians supply to overworked journalists. Political coverage has become more superficial, and research shows that politicians are increasingly image conscious and media-obsessed (Davis, 2010). In a nutshell, the media "wants" simple, ready-made sound bites - and the politicians deliver. This is, therefore, not just a case of media coverage, but also of politicians' behaviour and politics itself.

Since Iceland is one of the five Nordic countries, one would expect it to be in a somewhat better position to tackle the crisis of the news media than many other countries. The Nordic states have been defined in relation to the tradition of the welfare state and democratic corporatism - characteristics also apparent in the Nordic media landscape. These rich states have supported public and private outlets more than many other states (Syvertsen et al., 2014).

Despite being in a better position than in many countries, media organisations in the four more-populated Nordic states (Denmark, Finland, Norway, and Sweden) are also facing increased resource constraints. To some extent, this has not influenced political journalism as much as other types of reporting. There is still emphasis placed on specialised political reporters who cover traditional institutional politics in these states. One contributing economic factor behind such continuing priorities is that this type of news is relatively cheap to produce, particularly when compared to investigative forms 
of journalism (Allern et al., 2021). This type of journalism has been shown to influence politics itself in the other Nordic states. For example, studies in Denmark have shown how politicians have adapted their behaviour to suit news values such as conflicts and personalisation (Blach-Ørsten, 2014; Skovsgaard \& Dalen, 2013).

Iceland has been routinely overlooked in media and political communication research (Ólafsson \& Jóhannsdóttir, 2021) and is often simply defined as a Nordic model alongside the four states. But the Icelandic media market differs somewhat from the markets in the larger Nordic countries. Icelandic authorities have, up until now, not supported private media as has been done in Denmark, Finland, Norway, and Sweden (Ahva et al., 2017). Corporatism is less developed in Iceland than in the other four countries, and state involvement has been limited to RÚV, the public broadcasting service, whilst all other media have been based on commercial grounds. RÚV can also be seen as more commercialised than public broadcasting stations in the other Nordic countries. It has, from its foundation, been allowed to carry advertisements, and advertising sales amount to approximately one-third of its revenue. In this sense, RÚV has always also been a commercial station (Broddason \& Karlsson, 2005). Simply put, Iceland's media market does not fit into the funding model commonly used to describe the Nordic media system (Ohlsson, 2015). Another key difference concerns political journalists. Unlike in the more-populated Nordic states, there are hardly any specialised political journalists in Iceland. Most national journalists in the small country are generalists, similar to local journalists in Denmark, Finland, Norway, and Sweden (Ólafsson, 2019).

Since the news media has fewer financial resources than before, it has been necessary to focus on cost-cutting, and one of the targets has been journalists. Almost a third of the Icelandic journalist population was laid off following the financial crisis, among them many experienced journalists (Jóhannsdóttir, 2015; Kolbeins, 2012). This was the case at both private and public service outlets. In 2016, there were only 330 active journalists in the whole of Iceland registered with the Union of Icelandic Journalists (Guomundsson, 2016). Small media markets, like the one in Iceland, can be structurally more vulnerable than markets in larger democracies. Puppis (2009) shows how small media markets face limitations on the production side, compared to larger markets. Shortage of resources is a serious hurdle in news production. The markets are also limited on the sales side, with regard to advertising and audiences. A small and vulnerable commercialised media market like the one in Iceland was therefore vulnerable to begin with, and the financial crisis and its aftermath - with increased resource constraints and collapsing commercial funding models - made it even more vulnerable.

\section{Methods and data collection}

Answers from 50 semi-structured interviews with Icelandic journalists and politicians conducted between October 2016 and September 2017 are used to examine how they perceive routine political coverage in the Icelandic media. I interviewed 25 of the 63 sitting members of parliament (MPs) from all political parties represented in the Icelandic parliament at the time. This included 5 of the 11 government ministers. A purposive sample (Robson, 2011) was chosen that mirrored party representation in the parliament at the time. I also interviewed 25 journalists from the main media outlets in Iceland. 
Very few journalists in Iceland write exclusively - or even mostly - about politics, but a larger number focus to some extent on political issues. The criteria for being included in the sample for the journalist group was being employed at the time as journalists and editors and sometimes covering political issues.

All 50 interviews were conducted in Icelandic and were recorded and transcribed in full by myself. I have anonymised and translated answers to English. Most interviews were around one-hour long, with the shortest being 50 minutes and the longest 2 hours. I emphasised the investigation of perceptions relating to the media in general terms, with open questions. Specific examples of news topics and outlets were often mentioned by interviewees in their answers and are included where relevant. In most cases, it did not appear difficult for the interviewees to generalise about the Icelandic news media and the media market. I initially coded the interviews using the open coding approach and the software NVivo to qualitatively identify key themes. I subsequently used axial coding to reassemble the data that was fractured during the initial coding (Charmaz, 2006).

Answers from a representative survey are used to compare public perceptions to those of journalists and politicians. The survey was administered through the Social Science Research Institute (SSRI) at the University of Iceland. It was sent to 2,000 respondents via email on 30 May 2017, and a total of 1,264 people answered the survey, with a response rate of 63 per cent. ${ }^{1}$ The questionnaire consisted of 25 questions in Icelandic, most of them with answers on a five-point Likert scale. The questions and statements in the survey were devised to explore to what extent the public agreed or disagreed with journalists and politicians. Sometimes, the statement was the opposite of interviewee perceptions. This was done in order to prevent acquiescence bias in the answers (BaronEpel et al., 2010). In addition to the 25 questions included in the questionnaire, there were standard questions from the SSRI, focusing on age, income, gender, political views, and education. Apart from the standard questions, I devised all the questions in the survey in Icelandic and have translated them to English for the descriptive statistical analysis that follows the interview analysis.

\section{Journalists: Perceptions of superficiality, events, and parliament}

All 50 interviewees were asked the following open question: "How does the Icelandic media cover politics?" Over 90 per cent of the answers from the journalists were along similar lines: Whilst stating that there are sometimes exceptions, journalists perceive the coverage overall to be "superficial" and "shallow". Linked to this, answers focused on a "lack of analysis and criticism", "reactive coverage", and too much focus on simplistic "she said/he said statements" in the coverage of politics. One journalist (interview 4) stated the following:

The coverage is too superficial. Something happens and you often just rush to get a quote. What does this politician say about this? You get the views of the politicians and they can often get away with saying whatever they like. You get one politician saying one thing and then you find another one that says the opposite. Sometimes they say things that simply are not true and get away with it because we usually do not have time to fact-check what they say. 
Over two-thirds of the journalists stated that certain outlets and journalists sometimes cover politics in depth with informed criticism and analysis, but the overall consensus was that the coverage in general is too superficial.

In relation to the superficiality theme, interviewees mentioned repeatedly that Icelandic political coverage is heavily "event-based". They contrasted outlets in larger European countries to the Icelandic market. In the larger states, the media is also often focused on events, but, at the same time, it also initiates coverage. According to the journalists, the initiative for political stories seldom comes from the media, but rather from pre-planned events that take place. The journalists then show up to cover these events or cover them from their desks, as is increasingly common.

In relation to this, a majority of the journalists stated that political coverage is commonly focused on the Icelandic government, and ministers are often interviewed at the pre-planned events. There is also much attention on the parliament. Apart from the ministers, most political interviews are with the leaders of political parties, those who are in charge of committees, and a few MPs who are infamous for often saying "outrageous things", according to many journalists.

This focus on elite interviewees among journalists is not surprising, since many studies have shown that institutional sources, notably political elites, dominate as sources in political coverage (e.g., Barnett \& Gaber, 2001; Tiffen et al., 2014). Moreover, studies from the Nordic countries have shown how party leaders and well-known politicians are prevalent in political news reports (Allern et al., 2021). The Icelandic journalists often discussed this in relation to "talking heads" or "she said/he said" coverage. There is a lot of back and forth between elites in these political news stories, and they are often very negative and lacking in analysis and input from the journalists. These perceptions are somewhat different from studies from larger countries, such as the UK, that have shown an increasingly greater reliance on journalistic opinion and comment, enhancing the editorial power of journalists through "interpretive journalism" (Cushion, 2015). One of the journalists (interview 9) said:

There is little focus on the issues themselves and the emphasis is instead placed on disagreements and arguments. This is probably not good for the political debate in the society more generally. The media helps to illustrate differences between the parties. Usually we interview ministers, leaders of the political parties and MPs in charge of the parliamentary groups for each party. And they give opposing views.

Over 90 per cent of the journalists mentioned that the main focus in political news reports in the Icelandic legacy media, particularly on television and online, often lies on the heated debates that take place in the parliamentary chamber at the start of the day. These take place in short segments that are called störf pingsins [conduct of business of the parliament], fundarstjórn forseta [debates on parliamentary procedure], and óundirbúnar fyrirspurnir [questions to ministers without notice]. The first two provide MPs the opportunity to give short "sound bite friendly" speeches, usually delivered specifically for the media, according to the journalists. The third slot gives MPs the opportunity to ask ministers anything they like, and again, this is often delivered specifically for the media, as perceived by the journalists. One journalist (interview 2) described this:

Some members of parliament seem to have realised that if they say outrageous things or are witty and clever, they are more likely to be covered by the media. 
There is too much focus on arguments, shouting, and bullshit. Those who are loudest often get the most attention.

In contrast to the answers focusing on superficial coverage, many journalists stated that the media's coverage in the aftermath of the 2008 financial crisis was more critical than it had been before the crisis. The perception of many interviewees was that the criticism presented in the media in the aftermath of the crisis was not necessarily focused on policy debates, but rather that the media had allowed more critical voices to be heard. Put slightly differently, the critical coverage was not necessarily a consequence of journalists themselves becoming more discerning, but rather because attitudes in society were much more critical following the crisis, and this was reflected in the media. This can be linked back to the theme of the event-based coverage, but expanded to the societal level. Citizens, politicians, and various groups and organisations initiated more criticism, which was covered in the media. The Icelandic media was heavily criticised following the crisis, and journalists simply had to step up their game, according to most of the journalists interviewed. Many of them stated that this was done partly by opening up to more voices, but also by certain journalists and outlets being more critical than they would have been before the crisis.

Newer outlets, such as Stundin and Kjarninn, are often particularly critical and dig deep, according to many interviewees. The limitation with these two outlets is that they are much smaller than those who cover general news throughout the day, reach a smaller audience, and need to focus on narrower topics than the larger private outlets and RÚV. As one of the more senior journalists (interview 48) reflected, these smaller outlets perform well from time to time, but mainly in areas they are specifically interested in covering. As he put it, "This is often good work. But this is not representative of the media market overall".

Almost all of the journalists said that the routine coverage in general, as it relates to politics, has moved back to a less critical pre-financial crisis mentality. Much has changed in the last few years. In relation to this, another of the more senior journalists (interview 46) reflected on the time shortly after the Icelandic banks had collapsed:

This was a really interesting time. People were very interested in political issues and discussed them a lot. But the problem is that people just gradually sort of stopped taking part. The interest died down [...] So much happened here after the crisis. We had the parliamentary report on why the banks collapsed, and people tried to change the constitution. People were always protesting. But then these things sort of went nowhere.

Even though many things have gone back to a more pre-financial crisis mentality, a majority of interviewees agreed that one specific aspect has drastically changed: trust in the media and politics is still much lower than it was before the crisis, and this has impacted political coverage. Regarding this more critical post-crisis coverage, the importance of social media was noted. For example, one of the journalists (interview 5) said the following:

Yes, the crisis clearly had a big impact. The media was heavily criticised. Journalists are often more critical now than they used to be, but this is also linked to the fact that the public distrusts politicians and the media a lot more now compared 
to before the crisis. If people are unhappy with something that the media is doing, they will make themselves heard on social media. There is a lot of pressure on journalists from there. So, the media overall, and individual journalists and politicians, cannot get away with what they did before.

In other words, this is linked to public participation and public attitudes. At the same time, over 90 per cent of the journalists stated that the crisis and its aftermath have, overall, increased the problematic, uncritical, and superficial coverage. This was linked to developments in the media market, commercialisation, and limited funding. Following the crisis, media outlets have drastically shrunk in size, experienced journalists have moved to other jobs, and fewer (and less experienced) people are producing much more content than was the case prior to 2008.

A majority of the journalists mentioned how shallow sound bite coverage is often very dominant on the online news sites. A recent study appears to show a similar theme. Jóhannsdóttir (2020) examined the proportion of soft and hard news in Iceland's two main newspapers, Fréttablaðið and Morgunblaðið, as well as their accompanying online news sites at the time. She found that the amount of soft news increased in both print and online versions from 2005 to 2013 , but the increase was considerably more online.

One interviewed journalist (interview 32) stated succinctly, in relation to the online news sites, that "the internet is the weakest link. It is most vulnerable when it comes to the unfiltered news stories". This was frequently linked to the fact that the main online news sites in Iceland are reliant on web traffic and advertisements. Unlike in the other four more-populated Nordic states (Newman et al., 2019), there has been little focus on payment for online content in Iceland. What drives readership online is "clicks", and what matters is being first with the stories. This is how one of the online journalists (interview 33) explained the process of covering politics, mainly parliament, online in Iceland:

Usually just one of us covers the parliament for the day when it is in session. You follow it throughout the day on the screen in the office. There is a lot of emphasis put on oundirbúnar fyrirspurnir and störf pingsins. There is usually always something that comes from those two slots. And we often listen to special debates, but it takes too much time to listen to the longer debates. If I am watching one of the shorter debates, and I hear a really good quote, I try and type it up as fast as I possibly can and think that I need to be ahead of the other online sites. It is very important to be the first when you are online. It always amazes me how much the public is interested in these weird stories from the parliament that are not focused on the issues $[\ldots]$ We can follow what is being read in real time.

It is clear that the journalists interviewed were concerned about the state of the Icelandic media overall as it relates to political coverage. When asked how they perceived their roles as journalists, there were two prominent answers that can be related back to the ideal democratic roles of the media: holding those in power to account, staging an open and public debate on important issues, and speaking for the people and representing their interests (Curran, 2002). First, Icelandic journalists saw themselves as detached watchdogs, and, second, as disseminators of important information (see similar findings on Nordic journalists in Ahva et al., 2017). When commenting on the state of journalism, and whether it was good or bad, the assessment was usually discussed in relation 
to these role perceptions. In other words, the ideals were the normative reference point in their answers.

\section{Politicians: Overall agreement with journalists, but different insights}

Most of the politicians did mention some positive aspects with regard to how the Icelandic media covers politics. MPs stated that journalists sometimes come well prepared, and they have often been impressed by the overall quality of the questions posed. However, when asked the same open question as the journalists concerning how the Icelandic media covers politics, the general consensus quickly became apparent. The coverage is often "superficial" and "shallow", and too focused on "arguments", "negativity", "controversial statements" and "catchy headlines". Furthermore, the coverage is "too reactive", according to the politicians interviewed.

A majority of MPs mentioned that much of the real work in the parliament is not shown in the media, such as the work that takes place in the committees, and when MPs take part in policy debates. Instead, interviewees mentioned that the overarching focus is on heated debates and arguments that take place in the parliamentary chamber. This is mostly in the previously mentioned short slots at the beginning of the programme in the chamber, where MPs can give speeches on basically anything they like, and question ministers. And this is when most of the journalists pay attention, according to the MPs.

The way the programme for störf pingsins (the conduct of business of the parliament, most often mentioned by the MPs in relation to this) works is that there are usually 15 slots available, and MPs have to sign up at 8:00 in the morning for their slot. The segment normally lasts for half an hour and takes place twice a week. As one of the politicians (interview 16) stated, if you know what you are doing, you can basically control the media coverage you will get. You are, in a way, writing the news story for the journalists beforehand:

It is really easy to get yourself noticed in the media if you want to. The main thing is that, if you have something specific you want to get covered, then you go to störf pingsins, and you kind of need to be the first one. Because there are fifteen, and the journalist has maybe lost interest when it gets to thirteen, fourteen, and fifteen. You understand? In those slots. So you need to wake up early [laughs] to get your slot. You read the papers to find out what the story of the day is, and maybe you try to find something catchy to say or if there is an opening to have an argument with some other MPs. You try to get that in there. And this really works.

A majority of the MPs were critical of the way in which some politicians use the slots simply to get on the news and were equally critical of the media for covering this. Over two-thirds of the politicians mentioned that this type of political coverage is definitely not in the public interest.

Many MPs, particularly the younger ones, mentioned that they felt under some pressure to perform for the media in order to get attention - to prove that they are actually showing up for work. If they are being productive, but more behind the scenes, they often get comments from the public asking them what they are doing at work, and if they are in fact working, since they do not appear to be doing much. And the media is often uninterested in the committees and policy work, or unable to cover these areas due to resource constraints. Therefore, in order to get noticed - and demonstrate to people that 
they are really showing up - it is sometimes necessary to play the game with the media: to give the media "what it wants". One of the younger MPs (interview 18) explained:

Yes, the pressure, it is maybe indirect. That is, you do not really get noticed if you do not use certain, you know, unless you use big words. No one is telling you directly: "Say something really juicy so that I can use it." You know what I mean? But, you know, if you do not say something juicy, then of course I am not going to be using it. You understand? [laughs].

When giving a speech like this it is best to think like the journalist would, as several MPs illustrated. You create the headline yourself beforehand in your head and try to write the story for the journalist in the speech. Then it is ready-made for the media to pick up. As one MP (interview 15) put it:

We are not innocent, I mean MPs in general, not innocent because we are aware of this window that opens up, this little half an hour which is in fact open. To go up to the podium and just belt it out and grab a headline.

Politicians usually discussed this in relation to commercialisation and market-driven news values. That is, they showed an awareness that it is "necessary" to suit the superficial "headline grabbing" needs of the media. This not only affects what the media covers, but also what types of speeches are given in parliament, and so forth. In sum, it influences politics itself, not just the media coverage.

Similar to the journalists, the most common words used by the politicians to describe political coverage in the Icelandic media were "superficial" and "shallow". A majority of MPs compared the coverage to what they are familiar with in other countries, particularly in Europe (the UK and the Nordic countries were frequently mentioned). Most said that they follow various foreign news outlets, so they could easily compare the coverage between Iceland and the larger states. Over two-thirds agreed, that although the political coverage can also be superficial overseas, there exists more in-depth coverage there alongside the more superficial material. The dominant perception was that coverage in Iceland is often highly random, and what is reported clearly depends, to an extent, on the interests of the journalists who are working on any given day, according to many of the MPs. It was frequently mentioned that the media does not spend nearly enough time analysing important topics, such as the yearly budget and the five-year budget plan put forth by the government. Instead, too much focus is spent on less-complex argumentative issues that do not matter nearly as much for society in the long run, such as whether to expand the sale of alcoholic beverages.

According to a majority of the politicians, there is often little follow-up on important news reports, and many said that they are under the impression that stories are sometimes discontinued the following day if a particular journalist who had been covering the story is not working then. One of the older MPs (interview 29) expanded on this:

The political coverage in Iceland is far too shallow in general. I sympathise with the media outlets because they are short staffed and struggling financially. The shallowness of the coverage is a weakness. It is superficial and based around catchy headlines. What is lacking is depth and investigative journalism, but there are, of course, exceptions and good reporting here and there. What is also bad is that there is not much stamina to continue with stories. There are many sad examples 
of important topics that have not been covered thoroughly. What I am describing here is of course not unique to Iceland, but it is much more exaggerated here. The media often stays away from covering big and complicated issues. They are seen as too abstract, I think. It is easier for the media to cover more narrow issues that are linked to particular groups who are vocal and have shown an interest in them and put them on the agenda.

A majority of MPs mentioned similar points. They perceived journalists as usually working under immense pressure and not having time to work on their stories properly. The watchdog role, then, is often not really carried out by the journalists. Instead, special interest groups, opinion leaders, and members of the public put issues on the agenda, and they are frequently allowed to say what they want in the news reports, somewhat unfiltered. One group says one thing, and someone from another group says the opposite. The journalist disseminates the material, and then the story is commonly over.

The findings here are, to an extent, similar to what has been found previously in larger states in relation to superficial coverage (e.g., Davies, 2008; Karidi, 2018). However, the situation is perceived to be escalated in Iceland because of the smallness of its commercialised media market (Ólafsson, 2020). Most interviewees were easily able to generalise about the media market and argued that there is a lack of variety on display. These perceptions are not surprising. In a market as small as the Icelandic one, there is little room for readership segregation based on purchasing capacity and other socioeconomic divisions. Most media outlets do not focus on segments of the population that might have specialised interests, but rather cater to the public in this small media market (Jóhannsdóttir \& Ólafsson, 2018).

\section{Political coverage as perceived by the public}

There were clear similarities between interviewee perceptions and answers from the public. The first statement examined here concerned the superficiality of political coverage in the Icelandic media. Respondents were asked whether they agreed or disagreed with the statement that the coverage is superficial.

Table 1 Perceptions concerning the superficiality of political coverage

\begin{tabular}{lcr}
\hline & $\%$ & $95 \% \mathbf{C l}$ \\
\hline Strongly agree & 13 & $(11.1-14.9)$ \\
Somewhat agree & 40 & $(37.2-42.8)$ \\
Neither agree nor disagree & 33 & $(30.3-35.7)$ \\
Somewhat disagree & 13 & $(11.1-14.9)$ \\
Strongly disagree & 2 & $(1.3-2.7)$ \\
\hline
\end{tabular}

Comments: Respondents were asked to what extent they agreed or disagreed with the following statement: "Political coverage in the Icelandic media is generally superficial".

The answers were quite clearly in one direction, with the majority in agreement with interviewees. As Table 1 shows, ${ }^{2} 53$ per cent of respondents agreed with the statement, whilst only 15 per cent disagreed with it -33 per cent neither agreed nor disagreed. 
The second statement focused on whether the media asks questions that are critical enough when covering politics. The interviews suggested that the media is often not critical enough, and this was frequently discussed in relation to the watchdog role.

Table 2 Perceptions concerning critical questions in political coverage

\begin{tabular}{lcr}
\hline & $\%$ & \multicolumn{1}{c}{$95 \% \mathbf{C l}$} \\
\hline Strongly agree & 2 & $(1.3-2.7)$ \\
Somewhat agree & 21 & $(18.7-23.3)$ \\
Neither agree nor disagree & 29 & $(26.4-31.6)$ \\
Somewhat disagree & 34 & $(31.3-36.7)$ \\
Strongly disagree & 14 & $(12.0-16.0)$ \\
\hline
\end{tabular}

Comments: Respondents were asked to what extent they agreed or disagreed with the following statement: "The Icelandic media generally asks questions that are critical enough in its coverage of politics in Iceland".

Table 2 illustrates that almost half of the respondents (48\%) disagreed with the statement that the questions asked are critical enough; 23 per cent agreed with the statement and 29 per cent neither agreed nor disagreed. This is similar to the interviewees' observations.

The third statement examined whether the Icelandic media conducts enough investigative work when it covers politics in Iceland. The interviews suggested that the dominant perception is that the media does not conduct enough of its own work to initiate stories. Too much of the political coverage is reactive and event-based.

Table 3 Perceptions concerning investigative work in political coverage

\begin{tabular}{lcr}
\hline & $\%$ & $95 \% \mathbf{C l}$ \\
\hline Strongly agree & 2 & $(1.3-2.7)$ \\
Somewhat agree & 15 & $(13.0-17.0)$ \\
Neither agree nor disagree & 36 & $(33.3-38.7)$. \\
Somewhat disagree & 37 & $(34.3-39.7)$ \\
Strongly disagree & 11 & $(9.2-12.8)$ \\
\hline
\end{tabular}

Comments: Respondents were asked to what extent they agreed or disagreed with the following statement: "The Icelandic media generally conducts enough investigative work when it covers politics in Iceland".

As shown in Table 3, the answers were again quite clear. Only 17 per cent agreed with the statement that the media conducts enough investigative work when covering politics, whilst 48 per cent disagreed with it -36 per cent neither agreed nor disagreed.

The fourth statement focused on resources. Respondents were asked whether they agreed or disagreed with the statement that the Icelandic media has enough financial resources to produce quality political coverage. The interview answers suggested that journalists and politicians perceive the media as lacking in financial resources, which contributes to lower quality political coverage.

As Table 4 shows, more public respondents disagreed with the statement, and this suggests again that their perception of the situation is similar to the interviewees. Only 20 per cent of respondents agreed with the statement that the Icelandic media has enough 
financial resources, whilst 37 per cent disagreed with it. It is worth highlighting here that a very high percentage (44\%) neither agreed nor disagreed with the statement. In spite of the high percentage of these answers, it is still clear that, of those who either agreed or disagreed, a much larger percentage agreed than disagreed with the interviewee answers.

Table 4 Perceptions concerning the media's financial resources

\begin{tabular}{lrr}
\hline & $\%$ & $95 \% \mathbf{C l}$ \\
\hline Strongly agree & 3 & $(2.1-3.9)$ \\
Somewhat agree & 17 & $(14.9-19.1)$ \\
Neither agree nor disagree & 44 & $(41.2-46.8)$ \\
Somewhat disagree & 28 & $(25.5-30.5)$ \\
Strongly disagree & 9 & $(7.4-10.6)$ \\
\hline
\end{tabular}

Comments: Respondents were asked to what extent they agreed or disagreed with the following statement: "The Icelandic media generally has enough financial resources to be able to produce quality political coverage".

The fifth statement focused on whether the Icelandic media provides citizens with reliable information to judge politicians' work. The interview answers suggested that politicians perceive the media as not necessarily providing the public with this type of information. This perception was echoed in the answers from the journalists. The assumption appears to be that the media is failing in its democratic watchdog role when it comes to reporting reliably on those in positions of power in the political sphere.

Table 5 Perceptions concerning the reliability of information on politicians' work

\begin{tabular}{lrr}
\hline & $\%$ & $\mathbf{9 5 \% ~ C l}$ \\
\hline Strongly agree & 2 & $(1.3-2.7)$ \\
Somewhat agree & 24 & $(21.6-26.4)$ \\
Neither agree nor disagree & 40 & $(37.2-42.8)$ \\
Somewhat disagree & 28 & $(26.4-30.6)$ \\
Strongly disagree & 7 & $(5.6-8.4)$ \\
\hline
\end{tabular}

Comments: Respondents were asked to what extent they agreed or disagreed with the following statement: "The Icelandic media generally provides citizens with reliable information to judge politicians' work".

More respondents disagreed with the statement (35\%) than agreed with it (26\%), and the public therefore, once again, answered similarly to the interviewees. The difference here is smaller than in the previous answers focused on media performance and content. The public appears to be slightly less negative towards the media than journalists and politicians -40 per cent neither agreed nor disagreed.

The final statement examined from the questionnaire focused on whether political coverage in the Icelandic media generally gives an accurate picture of politicians' work in the parliament. Interview perceptions suggested that the media is mainly focused on superficial sound bite debates in the parliamentary chamber, and that journalists do not focus on much of the other work that takes place in parliament. Again, public perceptions 
appear to point in a similar direction as those of politicians and journalists. Only 21 per cent agreed with the statement, whilst 39 per cent disagreed. Thus, of those who agreed or disagreed, almost twice as many appear to be more in agreement with the perceptions of journalists and politicians -40 per cent neither agreed nor disagreed.

Table 6 Perceptions concerning accuracy in political parliamentary reporting

\begin{tabular}{lrr}
\hline & $\%$ & $95 \% \mathbf{C l}$ \\
\hline Strongly agree & 1 & $(1.3-2.7)$ \\
Somewhat agree & 20 & $(21.6-26.4)$ \\
Neither agree nor disagree & 40 & $(37.2-42.8)$ \\
Somewhat disagree & 28 & $(26.4-30.6)$ \\
Strongly disagree & 11 & $(5.6-8.4)$ \\
\hline
\end{tabular}

Comments: Respondents were asked to what extent they agreed or disagreed with the following statement: "Political coverage in the Icelandic media generally gives an accurate picture of politicians' work in the Icelandic parliament".

To sum up, in all six statements that relate to superficiality, critical coverage, investigative work, financial resources, reliable information, and the accuracy of coverage, there were far more respondents in agreement than disagreement with the dominant themes from the interviews. The statements examined can be related back to the ideal democratic roles of the media: serving as a watchdog, staging a debate, and speaking for the people and representing their interests (Curran, 2002). If the coverage is superficial, missing reliable and accurate information as well as investigative reporting, it is difficult to argue that the media is performing these roles well.

\section{Superficial coverage: A mix of smallness and funding}

What is described here in relation to superficial political coverage and shortage of resources is, of course, not unique to Iceland (e.g., McChesney \& Pickard, 2011). Perceptions from the interviews suggested, however, that there is concern that the situation in Iceland is much more extreme than in many other countries. When asked why the media coverage is the way it is in Iceland, the most dominant theme by far concerned the lack of resources in relation to the small-market commercial conditions. In short, it is a mix of smallness and funding.

Nearly all of the journalists interviewed said that their working conditions keep getting worse (both at the private outlets and RÚV) and that this has an impact on the quality of material they are able to produce. The salary being offered is very low compared to public relations and other linked areas of work, and the pressure is often almost unbearable. As one of them simply stated after discussing this (interview 2), "I often think after a long and difficult day: Why on earth am I doing this? Seriously?"

When discussing this, a large majority of interviewees brought up the issue of specialisation, or, more accurately, the lack of it. Few experienced journalists are left to cover political affairs, and there is, for example, only one journalist permanently based in the Icelandic parliament now. This is a very different situation from the press lobbies of the parliaments in the other four Nordic countries (e.g., Dalen \& Skovsgaard, 2010; 
Dindler, 2015). Most of the politicians interviewed pointed to structural factors related to the smallness of the Icelandic media market - rather than criticising the journalists themselves - when they discussed problems with the political coverage. As one of the senior politicians (interview 23) said when talking about how political coverage has changed:

There used to be more journalists permanently based here in the parliament, and this meant that there was more continuity in the coverage and there was more focus on covering news from the parliament. Now the coverage is very superficial. There are a lot of exciting things taking place, but it is usually just störf pingsins and similar slots that get the attention. These are usually the least interesting debates. People using big words at the start of the day... the political coverage is much more focused on headlines and short comments than before.

Interviewees often highlighted that the media in Iceland has never been particularly strong compared with larger states because of the smallness of the market, but now with increased commercialisation and less revenue, the situation has become much worse than it used to be. The themes of smallness and difficult market conditions were usually discussed as interlinked. When the market is structurally vulnerable to begin with, it is clear that it will face more difficulties than markets in the larger states. This was evident in the interview answers. As one of the more senior journalists (interview 48) put it succinctly, in relation to the aftermath of the financial crisis: "There were so few of us to begin with. So this was too big of a blow".

Most saw the larger outlets, including RÚV, as producing more superficial coverage than before. Content analysis of news reports in the Icelandic media shows a high level of similarity in content and suggests that homogenisation has increased considerably (Guðmundsson, 2012). The interview answers seem to echo this, although RÚV was often mentioned as having more resources than the private outlets. Interestingly, it was mainly the smaller outlets Kjarninn and Stundin, which were both created post-crisis by journalists and are largely funded through subscriptions and online donations, which were seen to be producing the most in-depth investigative coverage. But this was seen as somewhat sporadic and narrow, since these outlets are very small.

Another issue that was highlighted by many interviewees concerned concentrated media ownership. This was, however, usually seen to be much more problematic concerning financial news than routine political coverage, although the two are clearly interlinked, as many pointed out. There has been much talk about concentrated ownership in Iceland in recent years. When discussing this, most of the journalists mentioned this as more of a problematic issue on the editorial level (that is, with editors having to deal with owners). Journalists seldom interact with the owners in relation to their everyday work. This was also seen to be more dominant in editorial content than in news coverage, and at certain outlets. Put simply, this does not necessarily factor heavily in influencing the daily work concerning overall routine political coverage, according to the journalists.

When all is taken together, a dominant theme clearly emerged at the start of the interview process and continued throughout. There was agreement on this across the political spectrum and at all media outlets. Despite various other issues raised, resource constraints in relation to funding and smallness was by far the most common answer that emerged in the interviews when discussing the overall routine political coverage. It was 
argued that other issues like ownership, threats of lawsuits, and connections to politicians and political parties can influence reporting in relation to bias, self-censorship, and so on. This was, however, seen to be more of a potential problem when there is a big and important issue to report in the news, and in relation to key events, like elections, more on the editorial level, and at particular news outlets (not across the entire media market). The resource issue in relation to smallness was, by far, seen as the most pressing one that overall affects the daily working practices of journalists, and as a result, routine political coverage in Iceland.

\section{Conclusion}

As Iceland is one of the five Nordic states, one might assume that it could be in a somewhat better position to respond to the crisis of the news media than many other countries. However, according to the interviewees, the mix of smallness and mainly commercial funding models results in even more superficial and problematic coverage than in many larger states. The survey answers illustrate that the public does, to an extent, appear to agree with politicians and journalists. Most interviewees did not seem to find it difficult to generalise about the media market as a whole, although specific examples of media outlets and journalists doing a better job of disseminating important political information and holding those in power to account (particularly when some big event was taking place) were sometimes mentioned. What clearly emerged as a theme was a heavily homogenous small media system, very different from the ideals of media pluralism that highlight the democratic importance of a range of different voices being heard.

The fact that the data collection was based around routine political coverage led to some interesting findings. Problems related to ownership concentration and political parallelism were often discussed in relation to big events like elections and divisive pieces of legislation. Several of the interviews were conducted shortly after the election that was called following the Panama Papers scandal that resulted in the prime minister resigning. Despite this, hardly any interviewees brought this up and, instead, did not seem to find it difficult to generalise about the mundanity of the superficial political coverage and the democratic problems related to it. I argue that we must be careful not to overemphasise key events as representative of political coverage overall. Certain outlets in Iceland were seen to step up their game during key events for a limited time, but after that, things went back to "normal".

It is currently very difficult for journalists in Iceland to fulfil either the watchdog role or that of being an agency of information and debate. Superficial, homogenised and reactive coverage are clearly the opposite of what is required of the media, according to these ideals. The third key democratic ideal function of the media, according to traditional liberal theory, emphasises that the government is supervised by the people through the media between elections. Or, in more simple terms, it is often claimed that the media speaks for the people and represents their interests and views in the public domain (Curran, 2002). Perceptions concerning routine coverage in Iceland highlight that the media also appears to be struggling here. It is often more focused on reacting to what politicians say and do rather than supervising them on behalf of the people. 


\section{Notes}

1. Respondents were chosen from an online panel consisting of Icelandic residents aged 18 and older who have agreed to participate in the SSRI's online surveys. Panel members are recruited by telephone interviews with random samples from the Icelandic National Register and care is given to rebalancing when needed.

2. Answers in all tables are reported after weighing. This is so they represent the Icelandic population. Percentages represent completed answers for each question and are rounded, so they do not always add up exactly to 100 .

\section{References}

Ahva, L., van Dalen, A., Hovden, J. F., Kolbeins, G. H., Nilsson, M. L., Skovsgaard, M., \& Väliverronen, J. (2017). A welfare state of mind? Nordic journalists' conception of their role and autonomy in international context. Journalism Studies, 18(5), 595-613. https://doi.org/10.1080/1461670X.2016.1249005

Allern, S., Blach-Ørsten, M., Kantola, A., \& Pollack, E. (2021). Development trends and challenges in Nordic political journalism. In E. Skogerbø, Ø. Ihlen, N. N. Kristensen, \& L. Nord (Eds.), Power, communication, and politics in the Nordic countries (pp. 135-154). Gothenburg: Nordicom, University of Gothenburg. https://doi.org/10.48335/9789188855299-7

Barnett, S., \& Gaber, I. (2001). Westminster tales: The twenty-first century crisis in British political journalism. New York: Continuum.

Baron-Epel, O., Kaplan, G., Weinsten, R., \& Green, M. S., (2010). Extreme and acquiescence bias in a biethnic population. European Journal of Public Health, 20(5), 543-548.

Blach-Ørsten, M. (2014). The emergence of an increasingly competitive news regime in Denmark. In R. Kuhn, \& R. K. Nielsen (Eds.), Political journalism in transition: Western Europe in a comparative perspective (pp. 93-110). London: I.B. Tauris. https://doi.org/10.5040/9780755694723

Blumler, J. G., \& Kavanagh, D., (1999). The third age of political communication: Influences and features. Political Communication, 16(3), 209-230. https://doi.org/10.1080/105846099198596

Broddason, P., \& Karlsson, R. (2005). Medien in island [The media in Iceland]. In Hans-Bredow-Institut (Ed.), Internationales handbuch medien 2004/2005 [International Handbook of Media 2004/2005] (pp. 346-367). Baden-Baden: Nomos.

Charmaz, K. (2006). Constructing grounded theory: A practical guide through qualitative analysis. London: Sage.

Currah, A. (2009). What's happening to our news. Oxford: Reuters Institute for the Study of Journalism, University of Oxford.

Curran, J. (2002). Media and power. London: Routledge. https://doi.org/10.4324/9780203417744

Cushion, S. (2015). News and politics: The rise of live and interpretive journalism. London: Routledge. https:// doi.org/10.4324/9781315727646

Dalen, A. V., \& Skovsgaard, M. (2010). Korrespondent bag 'Borgens' beskyttende mure: Den danske politiske journalist og kommercialiseringen [Correspondent behind 'Borgens' protective walls: The Danish political journalist and commercialisation]. Politica, 42(3), 294-309.

Davies, N. (2008). Flat earth news. London: Chatto and Windus.

Davis, A. (2010). Political communication and social theory. London: Routledge. https://doi. org/10.4324/9780203847299

Davis, A. (2019). Political communication: A new introduction for crisis times. Cambridge: Polity.

Dindler, C. (2015). Negotiating political news: The two phases of off-the-record interaction. Journalism, 16(8), 1124-1140. https://doi.org/10.1177/1464884914555963

Guðmundsson, B. (2012). Umræðuvettvangur íslenskra dagblaða með hliðsjón af greiningarramma Colin Sparks [Icelandic newspapers in light of Colin Sparks's model of different types of press]. Stjórnmál \& stjórnsýsla, 8(2), 323-342. https://doi.org/10.13177/irpa.a.2012.8.2.7

Guðmundsson, F. P. (2016). Iceland's media market after the collapse of 2008: Fewer journalists - lighter material. Nordicom Information, 38(1), 41-45.

\section{Acknowledgements}

I would like to thank Aeron Davis and the two anonymous reviewers for their helpful comments. Parts of the research were supported by the Economic and Social Research Council in the UK (grant reference: ES/J500124/1) and the Power and Democracy Research Project at the University of Iceland. The research was conducted whilst I was based at Goldsmiths, University of London, but the article was finalised after I had moved to the University of Iceland. 
Jóhannsdóttir, V. (2015). Women in journalism: The situation in Iceland. Nordicom Information, 37(2), 33-40.

Jóhannsdóttir, V. (2020). Commercialization in the Icelandic press: An analysis of hard and soft news in major print and online media in Iceland in times of change. Journalism, 21(11), 1762-1778. https://doi. org/10.1177/1464884918768494

Jóhannsdóttir, V., \& Ólafsson, J. G. (2018). The Icelandic news media in times of crisis and change. Icelandic Review of Politics \& Administration, 14(1), 189-210. https://doi.org/10.13177/irpa.a.2018.14.1.9

Karidi, M. (2018). News media logic on the move? In search of commercial media logic in German news. Journalism Studies, 19(9), 1237-1256. https://doi.org/10.1080/1461670X.2016.1266281

Kolbeins, G. H. (2012, October). Siðferði og starfshættir íslenskra blaða- og fréttamanna [Ethics and working practices of Icelandic journalists] [Conference presentation]. Djóðarspegillinn 2012: Rannsóknir $i$ félagsvísindum XIII [Conference in social sciences]. http://hdl.handle.net/1946/13418

McChesney, R., \& Pickard, V. (2011). Will the last reporter please turn out the lights: The collapse of journalism and what can be done to fix it. New York: The New Press.

Newman, N., Fletcher, R., Kalogeropoulos, A., \& Nielsen, R. K. (2019). Reuters institute digital news report 2019. Oxford: Reuters Institute for the Study of Journalism, University of Oxford. https://reutersinstitute. politics.ox.ac.uk/sites/default/files/inline-files/DNR_2019_FINAL.pdf

Ohlsson, J. (2015). The Nordic media market: Denmark, Finland, Iceland, Norway, Sweden. Gothenburg: Nordicom, University of Gothenburg.

Ohlsson, J., \& Facht, U. (2017). Ad wars: Digital challenges for ad-financed news media in the Nordic countries, Gothenburg: Nordicom, University of Gothenburg.

Ólafsson, J. G. (2019). Media, democracy and small states: Political communication in Iceland [Doctoral dissertation, Goldsmiths, University of London, England]. https://doi.org/10.25602/GOLD.00026852

Ólafsson, J. G. (2020). Factoring size into the equation: Media studies, politics, and small states. Nordic Journal of Media Studies, 2(1), 145-156. https://doi.org/10.2478/njms-2020-0013

Ólafsson, J. G., \& Jóhannsdóttir, V. (2021). Media and politics in Iceland. In E. Skogerbø, Ø. Ihlen, N. N. Kristensen, \& L. Nord (Eds.), Power, communication, and politics in the Nordic countries (pp. 51-68). Gothenburg: Nordicom, University of Gothenburg. https://doi.org/10.48335/9789188855299-3

Phillips, A., \& Witschge, T. (2012). The changing business of news: Sustainability of news journalism. In P. Lee-Wright, A. Phillips, \& T. Witschge (Eds.), Changing journalism (pp. 3-20). London: Routledge. https://doi.org/10.4324/9780203809037

Puppis, M. (2009). Media regulation in small states. International Communication Gazette, 71(1-2), 7-17. https://doi.org/10.1177/1748048508097927

Robson, C. (2011). Real world research: A resource for users of social research methods in applied settings. Chichester: Wiley.

Siles, I., \& Boczkowski, P. J. (2012). Making sense of the newspaper crisis: A critical assessment of existing research and an agenda for future work. New Media \& Society, 14(8), 1375-1394. https://doi. org/10.1177/1461444812455148

Skovsgaard, M., \& Dalen, A. V. (2013). Dodging the gate-keepers? Social media in the campaigning mix during the 2011 Danish elections. Information, Communication \& Society, 16(5), 737-756. https.//doi $: 10.1080 / 1369118 X .2013 .783876$

Syvertsen, T., Enli, G., Mjøs, O. J., \& Moe, H. (2014). The media welfare state: Nordic media in the digital era. Ann Arbor, Michigan: University of Michigan Press. https://www.doi.org/10.3998/ nmw.12367206.0001.001

Tiffen, R., Jones, P. K., Rowe, D., Aalberg, T., Coen, S., Curran, J., Hayashi, K., Iyengar, S., Mazzoleni, G., Papathanassopoulos, S., Rojas, H., \& Soroka, S. (2014). Sources in the news: A comparative study. Journalism Studies, 15(4), 374-391. https://doi.org/10.1080/1461670X.2013.831239

(C) 2021 Nordicom and respective authors. This is an Open Access work licensed under the terms of the Creative Commons Attribution-NonCommercial-NoDerivatives 4.0 International Public licence (CC BY-NC-ND 4.0). To view a copy of the licence, visit https://creativecommons.org/ licenses/by-nc-nd/4.0/ 